\title{
FUNKCJONOWANIE I ROZWÓJ PORTÓW MORSKICH W CHIŃSKIEJ REPUBLICE LUDOWEJ
}

Porty morskie są miejscami szczególnie dogodnymi do lokalizacji różnego rodzaju działalności gospodarczej, zwłaszcza transportowej, handlowej, przemysłowej, logistycznej i innej usługowej. Wszystkie te rodzaje działalności wzajemnie się uzupełniają i umożliwiają tworzenie znacznej wartości dodanej, związanej z wszechstronną obsługa ładunków i przewożących je środków transportu, co wynika z realizacji podstawowego zadania wszystkich portów handlowych. Porty morskie pełnią istotne funkcje gospodarcze, które odzwierciedlają różnorodne współzależności pomiędzy rozwojem poszczególnych rodzajów wykonywanej w nich działalności gospodarczej a funkcjonowaniem i rozwojem tych obiektów oraz pomiędzy portami i ich otoczeniem. Celem artykułu jest pokazanie specyfiki chińskich portów morskich, które w ostatnich dekadach przeszły ewolucję i z obiektów na ogół mających znaczenie lokalne lub regionalne (oczywiście z wyjątkiem Szanghaju i Hongkongu), zarządzanych w systemie centralnym (państwowym) przekształciły się w porty wielkie, nowoczesne, obsługujące ogromne wolumeny różnorodnych ładunków (w tym kontenerów), otwarte na zagranicznych inwestorów, zarządzane w sposób zdecentralizowany, zajmujące czołowe pozycje w światowych rankingach.

Porty morskie jako ogniwa lądowo-morskich łańcuchów transportowych oraz ich najważniejsze funkcje gospodarcze

Definicje portu morskiego, występujące w literaturze przedmiotu, wskazują różne cechy i funkcje tego obiektu, akcentując najważniejsze aspekty decydujące o jego istocie. Port morski jest zatem usytuowany na styku lądu z morzem (albo w sąsiedztwie morza, np. w estuariach rzek), a jego obszar wyznaczają granice administracyjne (oddzielające go od otoczenia), jest wyposażony w odpowiednie składniki infrastruktury technicznej i suprastruktury, a także zasoby pracy i technologie niezbędne do prowadzenia złożonej działalności gospodarczej, polegającej na produkcji różnorodnych usług na rzecz ładunków, pasażerów i środków transportu. Podkreśla się też, że jest on złożonym węzłem transportowym o różnorodnych funkcjach. Klasyczna definicja, opisująca port morski jako miejsce w rejonie ze- 
tknięcia się lądu z morzem, w którym statki i ładunki korzystają z przygotowanej dla nich przystani i zorganizowanego aparatu usługowego ${ }^{1}$, wprawdzie pozostaje aktualna ze względu na podstawową funkcje portów, ale wskutek rozwoju przestrzennego i funkcjonalnego tych obiektów, obsługi coraz większego wolumenu ładunków, a zwłaszcza powszechnego rozszerzania ich działalności gospodarczej została rozszerzona. Współcześnie port morski powinien być postrzegany w kategoriach przestrzennych i technicznych, ale również ekonomicznych, logistycznych, administracyjnych i społecznych ${ }^{2}$.

Współczesne porty morskie, jako węzły w globalnym systemie transportowym, skupiające przedsiębiorstwa prowadzące różnorodną działalność gospodarcza, są integralnymi ogniwami lądowo-morskich łańcuchów transportowych ${ }^{3}$, łączących punkty nadania i odbioru ładunków ${ }^{4}$. Duże porty są złożonymi kompleksami produkcyjnymi o wielobranżowym profilu działalności, stanowiąc jednocześnie ważne elementy regionów nadmorskich i miast portowych. Stanisław Szwankowski podkreśla złożoność tych ośrodków gospodarczych, służących międzynarodowej wymianie towarowej oraz zróżnicowanej działalności o charakterze przemysłowo-handlowym ${ }^{5}$. Działalność gospodarcza w portach jest prowadzona na ogół przez wiele przedsiębiorstw oferujących różnorodne usługi na rzecz ładunków, pasażerów i środków transportu, ale często także przez przedsiębiorstwa przemysłowe ${ }^{6}$. Port jest zatem wielopodmiotowym organizmem gospodarczym, będącym złożoną organizacja, zarówno w sensie podmiotowo-kapitałowym, produkcyjno-przestrzennym, jak i funkcjonalno-zarządczym ${ }^{7}$. Stanowi on ośrodek podaży różnorodnych usług

1 L. Kuźma, T. Szczepaniak, Porty morskie. Gospodarka portowa w zarysie, Gdańsk 1971, s. 17.

2 H. Klimek, Porty morskie jako ogniwa ladowo-morskich tańcuchów transportonych oraz, ich funkecje gos= podarcze [w:] Porty morskie w perspektymie przestrzennej, ekonomicznej, transportowej, logistycznej i spotecznej, red. H. Klimek, Gdańsk 2016, s. 21.

3 Pod pojęciem lądowo-morskiego łańcucha transportowego należy rozumieć połączenie dwóch punktów transportowych, pomiędzy którymi ładunek odbywa cały kombinowany przewóz lądowo-morski. W takim łańcuchu może występować wielu przewoźników, zarówno z lądowych, jak i wodnych gałęzi transportu oraz moga pojawić się różne punkty transportowe (czyli miejsca zatrzymania i ewentualnego składowania ładunku w procesie transportowym). S. Szwankowski, Wspótzaležności funkecjonowania sketadników ladowo-morskich tańcuchów transportonych, Gdańsk 1994.

4 S. Szwankowski, Funkecjonowanie i rozwoój portów morskich, Gdańsk 2000, s. 32-32.

5 Ibidem, s. 34.

6 Liczba tych przedsiębiorstw w danym porcie i ich oferta usługowa są zróżnicowane, co wiąże się z wielkością portu, jego rolą w łańcuchach transportowych i logistycznych łańcuchach dostaw, systemem zarządzania portami i w portach. Z raportu pt. Polskie porty morskie jako biegun rozwoju gospodarczego kraju i regionów lokalizacji, przygotowanego w 2016 r. przez Actia Forum na zlecenie Bałtyckiego Terminalu Kontenerowego w Gdyni we współpracy z Radą Interesantów Portu Gdynia, wynika, że w polskim sektorze portowym funkcjonuje około 3,5 tys. przedsiębiorstw zaangażowanych we współpracę z 42 tys. podmiotów gospodarczych w całej Polsce.

A.S. Grzelakowski, M. Matczak, Wspótczesne porty morskie. Funkcjonowanie i rozuoój, Gdynia 2012, s. 12. 
portowych i jednocześnie rynek ich zbytu, gdzie pasażerowie, gestorzy ładunków, przewoźnicy morscy i lądowi zgłaszają popyt na te usługi.

Trzeba dodać, że obecnie załadowcy na potrzeby przemieszczenia swoich ładunków dokonują wyboru portu morskiego przez pryzmat całego łańcucha transportowego, którego jest ogniwem. Dlatego na współczesnych rynkach usług portowych walka konkurencyjna odbywa się właśnie pomiędzy łańcuchami transportowymi, a szczególną rolę odgrywają w niej operatorzy logistyczni, spedytorzy, operatorzy transportu multimodalnego, którzy wybierają optymalne z punktu widzenia swoich zleceniodawców trasy przewozu ładunków ${ }^{8}$. Efektem tego jest koncentracja produkcji usług transportowych (i innych towarzyszaccych im) w wybranych punktowych i liniowych elementach międzynarodowych sieci transportowych, a zatem także koncentracja strumieni ładunkowych w przewozach lądowo-morskich na niektórych szlakach (obejmujaccych porty morskie). Towarzyszy jej tendencja do przyciagania dodatkowej masy ładunkowej z powiększającego się obszaru ciążenia. Nasila się ona wyraźnie wraz z postępującym rozwojem globalnych łańcuchów dostaw i konteneryzacjị.

Rozwój międzynarodowego handlu towarami przetworzonymi i wzrost odległości przewozów spowodowały, że wymiana handlowa jest w coraz większym stopniu realizowana $z$ wykorzystaniem technologii kontenerowej (obecnie ładunki skonteneryzowane stanowią około $17 \%$ wolumenu światowego handlu morskiego i ponad połowę jego wartości) ${ }^{10}$. Wzrost wolumenu kontenerów w międzynarodowym transporcie morskim oraz wzrost wielkości statków do ich przewozu doprowadziły do ukształtowania się charakterystycznego dla relacji oceanicznych modelu organizacji żeglugowych serwisów liniowych. Polega on na ograniczeniu liczby portów morskich, do których zawijają wielkie kontenerowce na szlakach międzykontynentalnych, i koncentracji obsługi ładunków w dużych ośrodkach, odgrywających rolę bub'ow. W zasięgu ich oddziaływania pozostaja mniejsze porty, połączone z nimi serwisami liniowymi o charakterze feederowym (dowozowo-odwozowym). Organizacja żeglugi kontenerowej opiera się na systemie bub and spoke, polegającym na dostarczaniu ładunków z mniejszych portów tzw. feederami (tj. niewielkimi jednostkami) do dużych centrów przeładunkowych, gdzie następuje ich załadunek na wielkie kontenerowce przemieszczające się na szlakach transkontynentalnych do innych wielkich centrów przeładunkowych, w których ma miejsce transshipment, czyli wyładunek tych ładunków z wielkich kontenerowców i załadunek ich na mniejsze jednostki dostarczające je do mniejszych portów.

Taka tendencja prowadzi do różnicowania roli i znaczenia portów morskich w lądowo-morskich łańcuchach transportowych oraz w obsłudze wymiany towarowej realizowanej drogą morską, szczególnie w odniesieniu do ładunków skonteneryzowanych.

8 H. Klimek, Funkecjonowanie rynków ustug portowych, Gdańsk 2010, s. 198-199.

9 H. Klimek, J. Dąbrowski, Funkicja logistyczna portów morskich, „Logistyka” 2012, nr 4.

10 Review of Maritime Transport 2015, Report by the UNCTAD Secretariat, New York-Geneva 2015, s. 66. 
Wyróżnia się zatem porty o znaczeniu lokalnym (peryferyjne, o niewielkich obrotach ładunkowych, obsługiwane głównie przez statki żeglugi dowozowo-odwozowej), porty duże, o znaczeniu regionalnym (o większych niż lokalne obrotach ładunkowych, np. zlokalizowane nad Morzem Bałtyckim, bazowe dla linii dowozowo-odwozowych, a niekiedy oceanicznych) oraz porty wielkie, o znaczeniu globalnym, tzw. megaporty lub buby (centra przeładunkowo-składowe, zlokalizowane na głównych szlakach żeglugowych, obsługujące ładunki handlu morskiego w relacjach transkontynentalnych) ${ }^{11}$. Praktyka pokazuje, że spośród około 14,5 tys. portów i przystani morskich na świecie ${ }^{12}$, obsługujących ładunki handlu morskiego, zdecydowana większość to porty małe, o znaczeniu lokalnym, obsługujące poniżej $1 \mathrm{mln}$ ton ładunków rocznie.

Przyjmuje się, że w skali globalnej funkcjonuje obecnie około 1,5 tys. portów, które mają istotne znaczenie dla transportu i handlu międzynarodowego ${ }^{13}$. Widoczna jest tendencja ograniczania liczby portów, do których zawijają statki pływające w serwisach transkontynentalnych. Armatorzy sami zmierzają do tego, aby wielkie i szybkie kontenerowce zawijały do niewielkiej liczby portów, co jest podyktowane dążeniem do obniżania kosztów obsługi portowej statków. Konsekwencją zawinięć wielkich kontenerowców do niewielkiej liczby dużych portów jest konieczność uruchamiania serwisów dowozowo-odwozowych do portów mniejszych, o znaczeniu regionalnym i lokalnym, zlokalizowanych w pobliżu ostatecznych odbiorców ładunków. Trzeba dodać, że wielkie kontenerowce zabierają obecnie na pokład po kilkanaście, a nawet około 20 tys. kontenerów, natomiast statki feederowe mogą zabierać ich po kilka tysięcy ${ }^{14}$.

W lądowo-morskich łańcuchach transportowych porty morskie są ogniwami o szczególnym znaczeniu ze względu na ich usytuowanie na granicy dwóch odmiennych środowisk naturalnych, co powoduje, że są one punktami bramowymi, przez które ładunki muszą być przemieszczone na swojej drodze do zamorskiego miejsca przeznaczenia. Porty są też węzłowymi punktami transportu, co oznacza, że zbiegają się w nich linie transportowe właściwe różnym gałęziom transportu (poza morskim na ogół też transportu drogowego, kolejowego, niekiedy wodnego śródlądowego i prze-

11 Organizacja i funkecjonowanie portów morskich, red. K. Misztal, Gdańsk 2010, s. 15.

12 Różne źródła podają odmienne liczby. Trudno jednoznacznie wskazać rzeczywistą liczbę portów morskich funkcjonujących obecnie na świecie ze względu na ich różnorodność (zwłaszcza różnice w wielkości, znaczeniu dla międzynarodowej i krajowej wymiany towarowej, pełnione funkcje, krajowe klasyfikacje punktów transportowych itp.). Jak podaje M.G. Burns, na świecie funkcjonuje obecnie około 9 tys. portów morskich, spośród których 3,5 tys. to porty duże i średnie. M.G. Burns, Port Management and Operations, London-New York 2015, s. 105.

13 A.S. Grzelakowski, M. Matczak, Wspótczesne porty..., s. 7.

14 Największy obecnie na świecie kontenerowiec „MSC Oscar” (395,4 m długości, 59 m szerokości i zanurzenie $16 \mathrm{~m}$ ) może zabrać na pokład 19244 TEU (czyli kontenery 20-stopowe), w tym 1800 chłodzonych; jego nośność wynosi 197362 tony. www.portalmorski.pl (15.09.2016). Zob. H. Klimek, Polskie porty morskie - aktymni uczestnicy ladowo-morskich tańcuchów transportonych [w:] Wyæwania i problemy transportu morskiego, red. J. Dąbrowski, Gdańsk 2011, s. 83-85. 
syłowego). Są to więc wielogałęziowe (multimodalne) punkty transportowe, integrujące układy liniowe infrastruktury różnych gałęzi transportu. To w nich następuje koncentracja ładunków z różnych punktów nadania i ich dystrybucja do różnych miejsc przeznaczenia. Porty morskie na świecie obsługują co roku ponad 20 mld ton ładunków i około 2 mld pasażerów, a transport morski obsługuje ponad 80\% wolumenu handlu światowego (i ponad 70\% w ujęciu wartościowym), zatem znaczenie portów w lądowo-morskich łańcuchach transportowych wydaje się nie do przecenienia ${ }^{15}$.

Porty morskie jako elementy systemów transportowych krajów nadmorskich odgrywją znaczącą rolę nie tylko w gospodarkach narodowych tych państw, ale także w gospodarkach regionów i miast portowych. Prowadzi się w nich działalność transportową, logistyczna, handlową i przemysłową, które generują znaczną wartość dodaną dla portu, miasta i regionu portowego oraz kraju. Różnorodne współzależności występujące pomiędzy rozwojem poszczególnych rodzajów działalności gospodarczej wykonywanej w portach a funkcjonowaniem i rozwojem tych portów oraz pomiędzy portami i ich otoczeniem (zarówno tym bliższym, jak i dalszym międzynarodowym) określa się mianem funkcji portowych ${ }^{16}$. Te współzależności rozpatruje się w aspekcie ich potencjalnego i rzeczywistego wpływu na funkcjonowanie portu i jego oddziaływania na otoczenie, co daje możliwość przedstawienia jego roli w gospodarce. Uwzględniając rodzaje działalności portowej i charakter oddziaływania portów na otoczenie, wyróżnia się na ogół funkcje: transportowa logistyczna, handlowa, przemysłowa, obsługi ruchu pasażerskiego (według kryterium przedmiotowego) oraz miastotwórcza, miejska, regionotwórczą i regionalną (według kryterium przestrzennego) ${ }^{17}$.

\section{Porty morskie w Chinach}

Jednym z głównych czynników, które umożliwiły szybki rozwój chińskiej gospodarki, było przyjęcie w 1978 r. polityki otwartych drzwi i związanych z nią reform gospodarczych. Obserwowany w ostatnich kilku dekadach rozwój gospodarczy i wzrost wymiany towarowej zarówno krajowej, jak i międzynarodowej, w tym realizowanej drogą morską, a także napływ zagranicznych inwestycji bezpośrednich do Chin przyczyniły się do wzrostu znaczenia chińskich portów morskich. Zarówno potencjał usługowy portów, jak i wolumen obsługiwanych w nich ładunków wzrosły od początku lat 90. XX wieku na niespotykaną w świecie skalę (np. w porcie

15 UNCTAD podaje, że w 2014 r. obroty światowego handlu morskiego wyniosły 9,842 mld ton, co oznacza wzrost o 3,4\% w stosunku do roku poprzedniego. Review of Maritime Transport..., s. 5; zob. też: H. Klimek, Porty morskie jako ogniwa..., s. 25.

16 A.S. Grzelakowski, M. Matczak, Wspótczesne porty..., s. 74.

17 Ibidem, s. 75; Ekonomika portów morskich i polityka portowa, red. L. Kuźma, Gdańsk 2003, s. 13. 
Yingkou w latach 1990-2015 przeładunki wzrosły prawie 143-krotnie, w Ningbo 35-krotnie, w Tianjin 26-krotnie, w Szanghaju 5-krotnie, zaś dla porównania w Rotterdamie o $62 \%{ }^{18}$; tab. 1). W 2005 r. po raz pierwszy chiński port zajął pierwsze miejsce wśród największych portów morskich świata i sytuacja nie zmieniła się do dziś $^{19}$. Obecnie wśród 20 największych na świecie portów morskich znajduje się 14 chińskich (tab. 2).

W historii portów morskich Chińskiej Republiki Ludowej (od czasu jej powstania w 1949 r.) można wyróżnić trzy główne etapy:

1) początkowy (startowy), w latach 1949-1972 (liczba głębokowodnych stanowisk obsługi statków wynosiła około 100),

2) wzrostu, w latach 1973-1980 (na koniec było 137 stanowisk głębokowodnych),

3) szybkiego rozwoju, po 1980 r., trwający do dziśs ${ }^{20}$.

Wzrost zarówno popytu na towary pochodzące z importu, jak i wolumenu chińskiego eksportu przyczynił się do gwałtownego rozwoju portów morskich, które musiały dostosować swój potencjał usługowy do sytuacji rynkowej. Problem kongestii portowej wpłynął na podjęcie licznych inwestycji w infra- i suprastrukturę portowa, służących wzrostowi przepustowości istniejących portów oraz budowie nowych. Przystosowano nabrzeża i baseny portowe do obsługi coraz większych statków (w tym specjalistycznych) przewożących różnorodne rodzaje ładunków. Wiele inwestycji portowych dedykowano ładunkom skonteneryzowanym. Obecnie wśród 20 największych portów kontenerowych świata jest 9 chińskich (tab. 3), zaś w pierwszej setce jest ich 19.

Wraz ze zmiana całego system gospodarczego Chin nastapiły zasadnicze zmiany w gospodarce portowej. Ewolucję przeszedł system zarządzania portami. Z państwowego (centralnie sterowanego) ewoluował w kierunku zdecentralizowanego, zorientowanego rynkowo, ułatwiającego zaangażowanie w działalność operacyjną w portach zagranicznych inwestorów.

18 Z porównania wielkości przeładunków w portach w Hongkongu i w Rotterdamie w latach 1955 i 2015 wynika, że w pierwszym z nich wzrosły one w ciagu 60 lat 44-krotnie, zaś w drugim tylko 4-krotnie. Należy dodać, że port w Rotterdamie już przed II wojną światową był największym portem morskim w Europie (przeładowując w 1938 r. 42,371 mln ton ładunków), następnie po zakończeniu działań wojennych ustąił miejsca innym portom, a pozycję europejskiego lidera ponownie zdobył w 1955 r. (przeładowując 66,215 mln ton) i utrzymuje ją do dziś (obsługując 466,4 mln ton). W latach 1962-1986 port ten był największym portem świata, ale ustąpił miejsca w rankingu portom azjatyckim. Morski rocznik statystyczny, Gdynia 1960; Port statistics. A wealth of information. Make it happen, www.portofrotterdam.com (dostęp: 10.09.2016).

19 Najpopularniejszym sposobem określania wielkości portów morskich jest porównywanie wolumenu dokonywanych w nich przeładunków ogółem i z uwzględnieniem rodzajów obsługiwanych ładunków (można wówczas mówić np. o największych portach naftowych czy kontenerowych).

20 Devolution, port governance and port performance, eds. M.R. Brooks, K. Cullinane, Elsevier 2007, s. 334. 
Tabela 1. Największe porty morskie Chin w latach 1990-2015 (mln t)

\begin{tabular}{|r|l|c|c|c|c|c|c|c|c|c|}
\hline Lp. & Port morski & $\mathbf{1 9 9 0}$ & $\mathbf{1 9 9 5}$ & $\mathbf{2 0 0 0}$ & $\mathbf{2 0 1 0}$ & $\mathbf{2 0 1 1}$ & $\mathbf{2 0 1 2}$ & $\mathbf{2 0 1 3}$ & $\mathbf{2 0 1 4}$ & $\mathbf{2 0 1 5}$ \\
\hline 1. & $\begin{array}{l}\text { Ningbo } \\
\text { \& Zhoushan }\end{array}$ & 25,54 & $\mathbf{6 8 , 5 3}$ & 115,470 & 311,1 & $\mathbf{3 4 8 , 9}$ & 364,6 & 809,8 & 873,0 & 889,0 \\
\hline 2. & Szanghaj & 139,60 & 165,67 & 204,400 & 534,4 & 590,4 & 644,8 & 776,0 & 755,3 & 717,4 \\
\hline 3. & Tianjin & 20,63 & 57,87 & 95,660 & 401,3 & 459,9 & 477,0 & 500,6 & 540,0 & 541,0 \\
\hline 4. & Suzhou &. &. &. &. &. &. & 454,0 & 480,0 & 540,0 \\
\hline 5. & Guangzhou & 41,64 & 72,99 & 111,280 & 409,5 & 431,0 & 438,0 & 454,7 & 500,4 & 519,9 \\
\hline 6. & Qingdao & 30,34 & 51,30 & 86,360 & 350,1 & 372,0 & 407,3 & 450,0 & 480,0 & 500,0 \\
\hline 7. & Tangshan &. &. &. & 250,6 & 308,0 & 364,6 & 446,2 & 500,8 & 490,0 \\
\hline 8. & Dalian & 49,52 & 64,17 & 90,840 & 208,3 & 211,1 & 233,0 & 408,4 & 420,0 & 415,0 \\
\hline 9. & Rizhao & 9,25 & 14,52 & 26,740 & 221,0 & 252,6 & 281,0 & 361,0 & 353,0 & 361,0 \\
\hline 10. & Yingkou & 2,37 & 11,56 & 22,680 & 225,0 & 261,0 & 301,0 & 330,0 & 330,7 & 338,5 \\
\hline 11. & Hong Kong &. & 111,00 & 174,642 & 267,8 & 277,4 & 269,3 & 276,1 & 297,7 & 256,6 \\
\hline 12. & Qinhuangdao & 69,45 & 83,82 & 97,430 & 276,3 & 250,0 & 233,2 & 272,6 & 274,0 & 253,1 \\
\hline 13. & Shenzhen & 4,80 & 11,74 & 56,970 & 204,9 & 205,5 & 196,5 & 234,0 & 223,3 & 217,1 \\
\hline 14. & Xiamen & 5,29 & 13,14 & 19,650 & 127,3 & 140,9 & 155,1 & 191,0 & 205,0 & 210,0 \\
\hline
\end{tabular}

Źródło: Preeglad statystyczny 1982. Gospodarka morska, Wydawnictwo Instytutu Morskiego, Gdańsk 1983; Gospodarka morska. Przeglad statystyczny, Zakład Wydawnictw Naukowych Instytutu Morskiego, Gdańsk 1996; Rocznik statystyki miedsynarodowej 2000, GUS, Warszawa 2000; Rocznik statystyczny gospodarki morskiej, GUS Urząd Statystyczny w Szczecinie, Warszawa-Szczecin 2004; Port statistics. A wealth of information. Make it happen, www.portofrotterdam.com (dostęp: 10.09.2016); Devolution, port governance and port performance, eds. M.R. Brooks, K. Cullinane, Elsevier 2007, s. 333.

W ciagu ostatnich dekad chińska gospodarka przeszła ogromne zmiany. Wraz z rozwojem gospodarczym i wdrażanymi reformami zmiany dotknęły sektora portowego, zarówno w zakresie przepustowości potencjału usługowego, jego specjalizacji, jakości oferowanych usług, jak i oddziaływania na otoczenie, w tym globalne logistyczne łańcuchy dostaw.

\section{Zarządzanie chińskimi portami morskimi}

Przed 1984 r. państwowy (centralny) system zarządzania portami morskimi charakteryzował się tym, że zarówno działalność eksploatacyjna w portach (polegająca na świadczeniu różnorodnych usług na rzecz gestorów ładunków, armatorów oraz pasażerów), jak i administracyjna (w odniesieniu do terenów i infrastruktury portowej) pozostawała w gestii organów państwowych. Ministerstwo transportu było właścicielem portów morskich i sprawowało całkowitą kontrolę nad decyzjami i działalnością bieżącą oraz rozwojem portów (formułowało strategie, wyznaczało kierunki rozwoju portów, planowało działalność bieżącą i rozwój, czyli decydowało zarówno o ważnych inwestycjach infrastrukturalnych, jak i o zarządzaniu działalno- 
ścią operacyjna). Władze lokalne (zarówno na poziomie miast, jak i prowincji) nie miały realnego wpływu na zarządzanie zlokalizowanymi na ich terenach portami.

Pozytywnym aspektem takiego centralnego zarządzania chińskimi portami, zdaniem K. Cullinane'a i T.-F. Wang, była możliwość przygotowania narodowej strategii rozwoju portów i (w obliczu ograniczonych środków finansowych) koncentracja na budowie kilku wielkich portów ${ }^{21}$. Niewątpliwym mankamentem takiego systemu był brak motywacji i zainteresowania podnoszeniem efektywności gospodarowania przez menedżerów portowych i lokalne władze. Dotyczyło to także jakości usług portowych. Brak zainteresowania jej podnoszeniem i dostosowywaniem do oczekiwań usługobiorców był poważnym problemem we wszystkich chińskich portach morskich w tym okresie.

Kolejnym poważnym problemem był brak funduszy na sfinansowanie większości niezbędnych inwestycji portowych. Tylko nieliczne porty miały zapewnione finansowanie działalności bieżącej i rozwoju. Skutkiem takiej sytuacji były poważne kongestie ładunkowe w portach w latach 1981, 1983 i $1985^{22}$.

Uznając krytykę takiego system zarządzania portami morskimi, a w szczególności będące efektem jego wdrażania niedofinansowanie infra- i suprastruktury portowej, w czerwcu 1984 r. władze Chin postanowiły wdrożyć nowy system zarządzania w porcie Tianjin (wówczas jednym z największych w kraju). Polegał on na włączeniu do procesu zarządzania portem morskim władz miasta Tianjin.

W następnych latach podobne rozwiązanie (system państwowo-municypalny) zastosowano w prawie wszystkich chińskich portach morskich (z wyjątkiem Qinhu$\operatorname{angdao}^{23}$ ), angażując do procesu zarządzania władze lokalne. Przekazano im także w całkowite władanie małe porty, o znaczeniu lokalnym, nieodgrywające większej roli w obsłudze międzynarodowego handlu morskiego.

W omawianym okresie wyraźna była nie tylko decentralizacja systemu zarządzania portami morskimi w Chinach, ale także polityki rozwoju portów. Zezwolono na podejmowanie i finansowanie inwestycji w portach zarówno władzom lokalnym, jak $\mathrm{i}$ inwestorom zagranicznym i bankom komercyjnym.

W 1987 r. powołano pierwsze chińsko-zagraniczne przedsiębiorstwo portowe Nanjing International Container Company Ltd. (joint venture Nanjing Port Authority i amerykańskiego Encial Terminals). To wydarzenie rozpoczęło nowy etap w polityce rządu Chin wobec zagranicznych inwestorów portowych. Odtąd byli oni nie tylko tolerowani, ale wręcz aktywnie zachęcani do inwestowania w chiński sektor portowy. Przyjęto też stosowne regulacje prawne (Interim Regulations of the State Council of the PRC Preferential and Wharf Construction oraz Instructions on

\footnotetext{
21 Ibidem, s. 343.

22 Ibidem, s. 344.

23 Po 1987 r. port w Qinhuangdao był jedynym portem centralnie sterowanym w Chinach. Ibidem, s. 344.
} 
Reform and Further Development of Transportation System). Spółki joint venture w tym okresie były jedyną formą portowych inwestycji zagranicznych w Chinach. Jednakże udziały w nich zagranicznych podmiotów mogły wynosić najwyżej 49\%.

Jednym z narzędzi zachęcania zagranicznych inwestorów była realizowana wówczas przez chińskie władze polityka rozwoju transportu, wzorowana na rozwiązaniach zagranicznych (m.in. system bub and spoke). Miała ona służyć podniesieniu konkurencyjności portów morskich na międzynarodowych rynkach usług portowych (zwłaszcza wobec konkurencji Singapuru i portów Tajwanu).

Pomimo ograniczenia możliwości udziału zagranicznych inwestorów (co studziło ich entuzjazm) na początku XXI w. w znacznej części portowego potencjału usługowego w Chinach swój udział miały liczne zagraniczne przesiębiorstwa ${ }^{24}$. Wyraźne było też wzmocnienie pozycji lokalnych zarządów portów. Jako podmioty zarządzające były one regulatorami polityki portowej, łącząc interesy rządu centralnego i władzy lokalnej, czyli podmiotami mającymi uprawnienia do podejmowania najważniejszych decyzji w sprawach rozwoju portów, doboru inwestorów zagranicznych. Jednakże były to przedsiębiorstwa państwowe (tzw. state-owned enterprises SOE-s), z wszystkimi związanymi z tym faktem ograniczeniami, które były zmuszone do funkcjonowania w otoczeniu rynkowym, zwłaszcza wobec działalności konkurentów zagranicznych. Począwszy od lat 90. XX w., rząd chiński próbował pozbawić je wielu autonomicznych funkcji, gdyż zaczęły ewoluować w kierunku „prawdziwych” (jak w gospodarce rynkowej) podmiotów gospodarczych.

Do 2001 r. publiczne zarządy portów w Chinach zajmowały się zarówno zarządzaniem infrastruktura i terenami portowymi, jak i świadczeniem usług na rzecz usługobiorców. Dzięki reformom systemu portowego ich funkcje przejęły dwie grupy podmiotów: administrowaniem zajęły się portowe organy (biura) administracyjne (w niektórych miastach portowych tę funkcję pełnią lokalne departamenty administracji transportowej ${ }^{25}$ ), zaś działalnością usługową podmioty niepubliczne, w szczególności krajowe i zagraniczne przedsiębiorstwa prywatne, w tym wielcy operatorzy terminali. Władze miast portowych (z pominięciem władzy centralnej) są upoważnione do przyciagania inwestorów zagranicznych do portów.

Proces reformowania chińskiego sektora portowego, polegający na odejściu od najwyższego stopnia centralizacji decyzji dotyczących administrowania oraz działalności eksploatacyjnej i przyjęciu (sprawdzonego w wielu krajach o gospodarce rynkowej) modelu oddzielenia (decentralizacji) tych dwóch obszarów działalności,

${ }^{24}$ Szczególną aktywność w inwestowaniu w chińskich portach na przełomie XX i XXI w. wykazali: port Singapur (PSA International) w portach w Szanghaju, Tianjin, Guangzhou, Dalian i Fuzhou, Ningbo, Xiamen; APM Ports w portach w Szanghaju, Shenzen, Qingdao, Xiamen i Dalian; DP World w portach w Szanghaju, Shenzen, Qingdao i Tianjin; Modern Terminals Ltd. w porcie w Shenzen; P\&O Ports w portach w Shenzen i Qingdao. Ibidem, s. 346.

25 Ibidem, s. 354. 
przyczynił się do wielkiego sukcesu chińskich portów na międzynarodowych rynkach usług portowych.

Nowy rozdział w historii chińskich portów morskich rozpoczął się w $2004 \mathrm{r}$. Wprowadzono wówczas tzw. prawo portowe (The Port Law) i jego uzupełnienie w postaci zasad zarządzania i prowadzenia działalności operacyjnej w portach (The Rules on Port Operation and Management) ${ }^{26}$. Były to pierwsze chińskie regulacje prawne dotyczące sektora portowego i uwzględniające jego znaczenie dla gospodarki kraju. Dały one szansę na stworzenie nowoczesnych przedsiębiorstw w sektorze portowym i określały zasady interwencji państwa w sferę zarządzania portami oraz w sferę działalności eksploatacyjnej na terenach portowych.

Wcześniej, jak wspomniano, zarządy portów były zarówno regulatorami rynku, jak i operatorami na rynkach usług portowych. Powodowało to poważne ograniczenie konkurencji i utrudniało rozwój sektora portowego w Chinach. Funkcję podmiotów zarządzających portami pełniły regionalne lub miejskie biura administracji portowej (Port Administration Bureau), np. w Szanghaju lub Liaoning, albo regionalne lub miejskie departamenty administracji transportowej (Transporttion Administration Deparment), np. w Guangdong lub Zhejiang ${ }^{27}$.

Zgodnie z nowym prawem portowym rząd chiński nie mógł pozostawać właścicielem przedsiębiorstw portowych. Dotychczasowe porty publiczne, których właścicielem lub współwłaścicielem był rząd centralny, miały zostać przekazane władzom regionalnym lub miejskim. Rząd centralny i jego regionalne (lub lokalne) organy administracyjne są obecnie odpowiedzialne za planowanie strategiczne i politykę rozwoju całej krajowej sieci portów morskich. Prawo portowe zdefiniowało zależności pomiędzy planowaniem strategicznym na szczeblu centralnym i lokalnym. Plany strategiczne dla sektora portowego, przygotowywane przez lokalne/regionalne organy władzy, powinny być przedstawiane do akceptacji rządowi centralnemu i nie mogą być sprzeczne z głównymi kierunkami rozwoju portów chińskich wskazywanymi przez rząd.

Prawo portowe, poza procesami zarządzania portami, reguluje też procesy inwestowania w portach. Zarówno krajowi, jak i zagraniczni operatorzy mogą oferować usługi na rynkach usług portowych w Chinach. Co ważne, zniesiono limit udziału inwestorów zagranicznych we własności przedsiębiorstw portowych. Oznacza to, że mogą oni inwestować w potencjał usługowy w portach oraz prowadzić działalność operatorską bez potrzeby zakładania spółek joint venture.

Podsumowując dotychczasowe rozważania o zarządzaniu chińskimi portami, należy stwierdzić, że wprowadzone w 2004 r. nowe prawo portowe skierowało chiński sektor portowy na tory gospodarki rynkowej, stwarzając warunki do prowadzenia efektywnej działalności eksploatacyjnej przez prywatnych (krajowych lub zagranicznych) operatorów, zaś państwu pozostawiając planowanie kierunków rozwoju ca-

26 Ibidem, s. 337.

27 Ibidem, s. 348. 
łej sieci krajowych portów morskich, funkcjonujących na bardzo konkurencyjnych rynkach usług portowych. Wdrażanie nowych, korzystnych z punktu widzenia działalności eksploatacyjnej w portach, rozwiązań prawnych przyczyniło się do wzrostu i umocnienia pozycji chińskich portów morskich na globalnym rynku usług portowych. Od 2005 r. niezmiennie chińskie porty zajmują pierwszą pozycję w rankingu największych portów morskich świata, w tym także portów kontenerowych.

Obecnie, zgodnie z prawem portowym, porty są na ogół w posiadaniu i pod zarządem władz lokalnych (różnego szczebla) w powiązaniu z krajowymi i zagranicznymi przedsiębiorstwami prywatnymi, którym umożliwiono zarówno udział w zarządzaniu i inwestowaniu, jak i własności potencjału produkcyjnego ${ }^{28}$.

\section{Chińskie porty morskie na rynkach usług portowych}

Chiny mają obecnie bardzo dynamicznie rozwijający się sektor portowy. Jest on szczególnie ważnym elementem chińskiej sieci logistycznej. Większoóć największych chińskich miast posiada porty morskie lub jest zlokalizowana w ich sąsiedztwie. $\mathrm{Na}$ liczącym około 18 tys. km wybrzeżu można wskazać trzy główne regiony portowe (ryc. 1), w których funkcjonuja porty o największym znaczeniu nie tylko dla gospodarki ChRL, ale także dla globalnych logistycznych łańcuchów dostaw. Są to:

1) region delty Rzeki Żółtej i Morza Bohai na północnym wybrzeżu (z największymi portami: Tianjin, Qingdao i Dalian),

2) region delty rzeki Jancy na środkowym wybrzeżu (z największymi portami: Ningbo/Zhoushan i Szanghaj),

3) region delty Rzeki Perłowej na południowo-wschodnim wybrzeżu (z największymi portami: Hongkong, Guangzhou i Shenzen).

Chiński sektor portowy obejmuje łącznie 172 główne porty morskie i śródlądowe, dysponujące okpło 32 tys. miejsc postojowych dla statków (w tym około 6 tys. w portach morskich, a wśród nich około 2,5 tys. głębokowodnych) oraz ponad 2 tys. pozostałych mniejszych portów ${ }^{29}$.

W 2014 r. chińskie porty morskie obsłużyły łącznie ponad 12,45 mld ton ładunków (co oznaczało wzrost o 5,8\% w stosunku do roku poprzedniego; tab. 2). W zasadzie obsługiwane są w nich wszystkie rodzaje ładunków zarówno suchych (węgiel, rudy żelaza i innych metali, inne surowce mineralne, zboże, chemikalia suche),

28 Ibidem, s. 349.

29 Za nabrzeże głębokowodne w chińskich statystykach uznaje się takie, przy którym może być obsługiwany statek o nośności 10 tys. dwt. Niestety, brak jest danych o liczbie nabrzeży i stanowisk statkowych, przy których mogą być obsługiwane największe statki, o zanurzeniu $15 \mathrm{~m}$ i więcej. Dane za: China ports. Opportunities for Dutch companies, www.nlambassade.org/binaries/ content/assets (dostęp: 15.09.2016). 


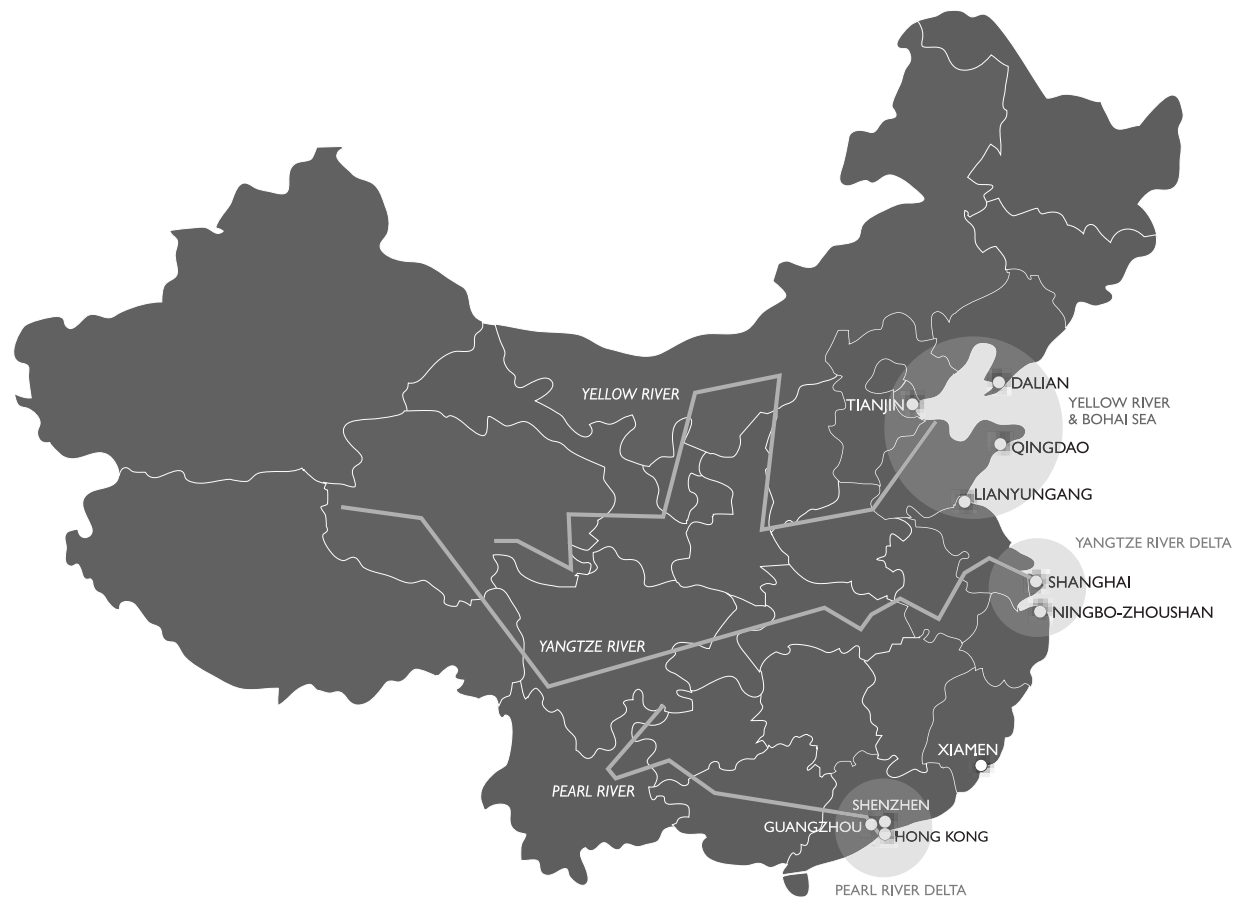

Ryc. 1. Najważniejsze regiony portowe w Chinach

Źródło: China ports. Opportunities for Dutch companies, s. 14, www.nlambassade.org/binaries/content/assets (dostęp: 15.09.2016).

jak i płynnych (ropa naftowa i jej przetwory, chemikalia płynne, gaz), a także ładunki zjednostkowane, zwłaszcza skonteneryzowane.

W 2014 r. chińskie porty kontenerowe (morskie i rzeczne) obsłużyły łącznie $202 \mathrm{mln}$ TEU, co oznaczało wzrost o $6,4 \% \mathrm{w}$ stosunku do roku poprzedniego ${ }^{30}$. Spośród 20 największych morskich portów kontenerowych świata 16 jest zlokalizowanych w Azji (w tym 9 w Chinach; tab. 3). Lącznie obsługują one 45,7\% światowych portowych obrotów kontenerowych, tj. ponad $310 \mathrm{mln}^{\mathrm{T}} \mathrm{TEU}^{31}$. Natomiast w pierwszej dziesiątce największych morskich portów kontenerowych na świecie jest 7 chińskich, które w 2014 r. obsłużyły 148,23 mln TEU, zaś w 2015 r. 150,6 mln TEU.

30 W chińskich statystykach oraz Review of Maritime Transport 2015 wyniki przeładunkowe portów ogółem podawane są łącznie. Dane dotyczące obrotu kontenerowego, tj. pojemności statków, przepustowości terminali portowych, wielkości przeładunków i przewozów, wyraża się liczbą TEU (twenty-foot equivalent unit), czyli kontenerów 20-stopowych. Review of Maritime Transport..., s. 66.

$31 \mathrm{~W}$ portach morskich na świecie przeładowuje się około $700 \mathrm{mln}$ TEU rocznie. Ibidem, s. 68. 


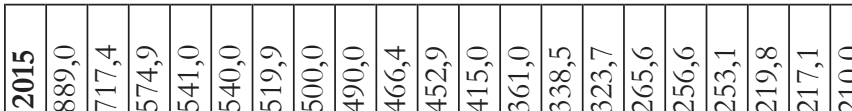

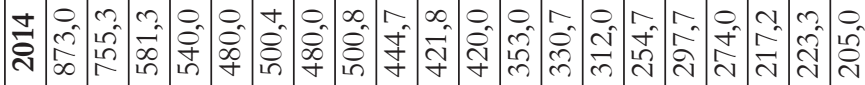

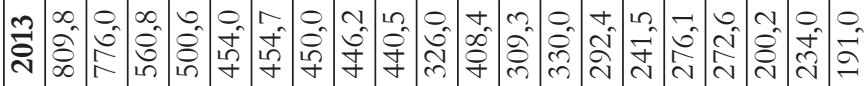

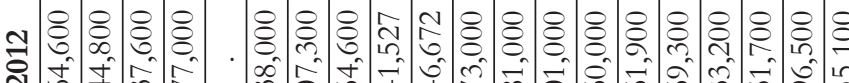

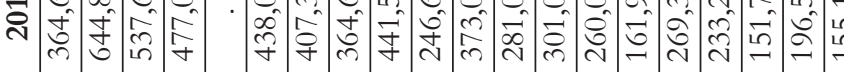

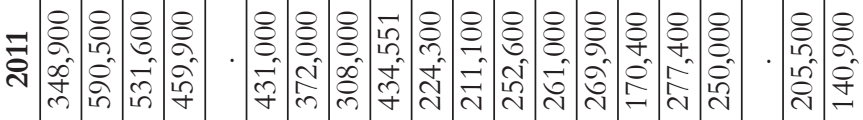

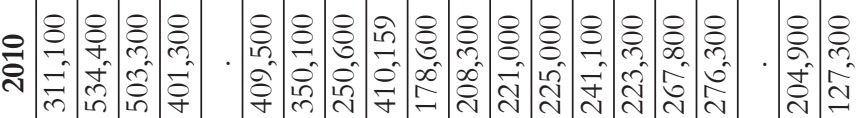

E

\begin{tabular}{|c|c|c|c|c|c|c|c|c|c|c|c|c|c|c|c|c|c|c|c|c|}
\hline 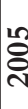 & \begin{tabular}{l}
$\varrho$ \\
\multirow{+}{*}{} \\
N \\
N
\end{tabular} & \begin{tabular}{l}
$\S$ \\
$\S$ \\
? \\
\multirow{+}{*}{}
\end{tabular} & 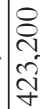 & 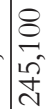 & $\cdot$ & 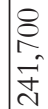 & 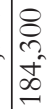 & $\cdot$ & $\begin{array}{l}\mathfrak{n} \\
\stackrel{n}{N} \\
\stackrel{n}{m}\end{array}$ & $\begin{array}{l}\varrho \\
\varrho \\
\varrho \\
己\end{array}$ & 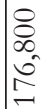 & $\cdot$ & 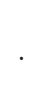 & 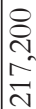 & 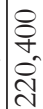 & 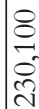 & 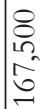 & $\begin{array}{l}\varrho \\
\Omega \\
\Omega \\
\varrho\end{array}$ & 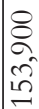 & $\mid \begin{array}{l}\varrho \\
\varrho \\
\varrho\end{array}$ \\
\hline
\end{tabular}

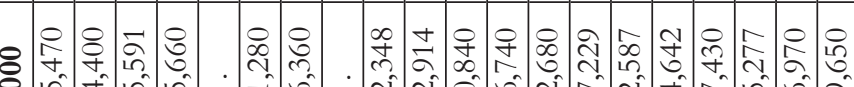

ปิ

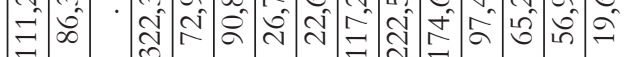

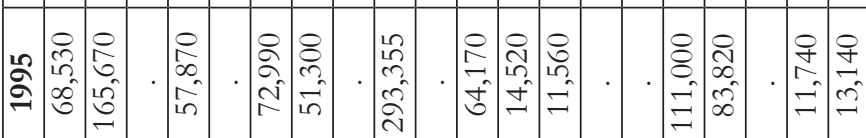

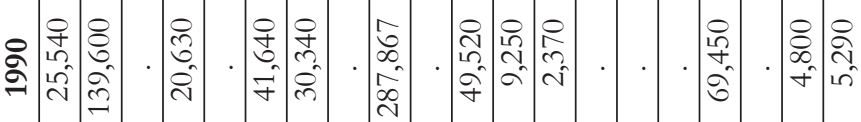

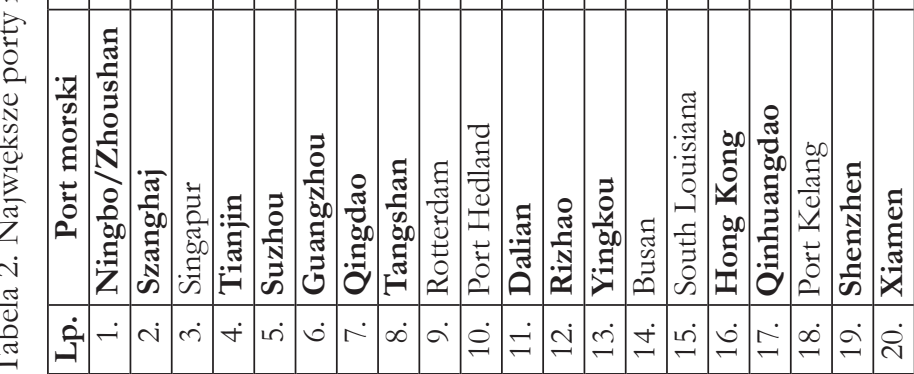

$\frac{2}{2}$

2

$\ddot{m}$

s

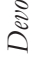

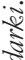

है

放

ริ้

है

है

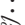

క

韪

낸

艾

है

ำ

$\therefore \frac{1}{7}$

$\because \ddot{0}$

.

:

\&

ह

$\circ$ :

实苛

.

: సٓำ

$3 \equiv$

द तิ

을 농

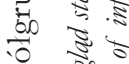

ह

苟

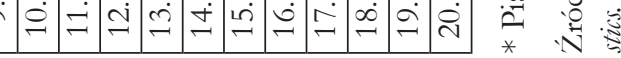




\begin{tabular}{|c|c|c|c|c|c|c|c|c|c|c|c|c|c|c|c|c|c|c|c|c|}
\hline$\frac{10}{0}$ & 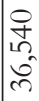 & 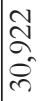 & 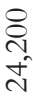 & 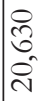 & 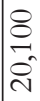 & $\begin{array}{l}\sqrt{0} \\
+ \\
0 \\
1\end{array}$ & 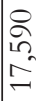 & $\underset{m}{2}$ & $\begin{array}{l}0 \\
\text { in } \\
\text { nf } \\
\text { n }\end{array}$ & $\begin{array}{l}\underset{Z}{\sqsupset} \\
\underset{\sim}{ \pm}\end{array}$ & $\begin{array}{l}\text { n } \\
\text { r } \\
\text { N } \\
\end{array}$ & 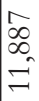 & 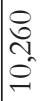 & $\begin{array}{l}+ \\
\text { L } \\
6 \\
0\end{array}$ & 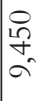 & $\frac{\infty}{\sigma^{\circ}}$ & $\frac{\rho}{a}$ & $\underset{N}{\infty}$ & $\underset{\infty}{\infty}$ & $\frac{\Omega}{2}$ \\
\hline$\frac{ \pm}{\delta}$ & $\begin{array}{l}0 \\
\text { ก } \\
\text { ก } \\
\text { m }\end{array}$ & $\begin{array}{l}\hat{b} \\
\infty \\
m \\
m\end{array}$ & 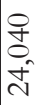 & 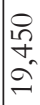 & $\begin{array}{l}Ð \\
\underset{N}{N} \\
\sim \\
N\end{array}$ & $\begin{array}{l}\infty \\
\infty \\
\infty \\
\infty\end{array}$ & $\begin{array}{l}0 \\
\sigma \\
\sigma \\
\sigma \\
=\end{array}$ & 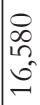 & 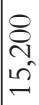 & 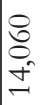 & ָे & 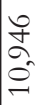 & $\begin{array}{l}m \\
\tilde{n} \\
0 \\
\tilde{n}\end{array}$ & $\begin{array}{l}\infty \\
\hat{\sigma} \\
\infty\end{array}$ & $\stackrel{\rho}{\rho}$ & $\begin{array}{l}N \\
1 \\
\infty \\
\infty\end{array}$ & $\begin{array}{c}\varrho \\
\text { மn } \\
\infty\end{array}$ & $\frac{\mathfrak{N}}{\stackrel{0}{N}}$ & 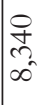 & $\begin{array}{l}\infty \\
\infty \\
\sigma\end{array}$ \\
\hline$\stackrel{m}{\tilde{D}}$ & $\begin{array}{l}\sigma \\
\sigma \\
m \\
m\end{array}$ & $\begin{array}{l}a \\
\text { in } \\
\text { ñ } \\
\text { ñ }\end{array}$ & $\begin{array}{c}a \\
N \\
\sim \\
\sim \\
N\end{array}$ & 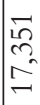 & No & $\begin{array}{l}0 \\
\infty \\
0 \\
1 \\
=\end{array}$ & $\begin{array}{l}\mathfrak{g} \\
\text { n? } \\
\text { n }\end{array}$ & $\begin{array}{l}0 \\
\text { N } \\
\text { in } \\
\text { 으 }\end{array}$ & 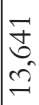 & $\begin{array}{l}\varrho \\
\wp \\
\text { m }\end{array}$ & $\begin{array}{l}\underset{\widetilde{\sigma}}{\sigma} \\
\underset{\sigma}{\sigma}\end{array}$ & $\begin{array}{l}0 \\
\text { in } \\
\text { n } \\
0 \\
?\end{array}$ & $\begin{array}{l}\infty \\
\tilde{n} \\
\hat{\sigma} \\
\tilde{n}\end{array}$ & $\begin{array}{l}\infty \\
\text { in } \\
\infty\end{array}$ & $\begin{array}{l}n \\
\sigma \\
0 \\
0\end{array}$ & $\underset{\infty}{\infty}$ & $\underset{N}{\infty}$ & in & $\underset{\infty}{\infty}$ & 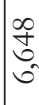 \\
\hline$\frac{N}{\mathbb{N}}$ & $\begin{array}{l}\text { थि } \\
\text { लि }\end{array}$ & $\frac{\tilde{\sigma}}{n}$ & ปे & $\begin{array}{l}\infty \\
\infty \\
\sigma\end{array}$ & $\stackrel{\sim}{\sim}$ & $\underset{\sigma}{\square}$ & $\frac{\checkmark}{\sim}$ & $\begin{array}{l}0 \\
\text { ए } \\
\pm \\
\square\end{array}$ & $\stackrel{\rho}{m}$ & $\begin{array}{l}\stackrel{p}{\sim} \\
\sim\end{array}$ & $\stackrel{\infty}{\approx}$ & $\begin{array}{l}\varrho \\
\varrho \\
\varrho\end{array}$ & $\frac{\infty}{a}$ & $\underset{\infty}{\varpi}$ & $\hat{\curvearrowright}$ & 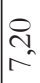 & $\frac{O}{N}$ & 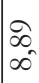 & $\underset{\infty}{\infty}$ & $\begin{array}{l}0 \\
0 \\
0\end{array}$ \\
\hline 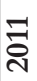 & $\stackrel{+}{\sim}$ & ఫે & กิ & $\stackrel{N}{ \pm}$ & $\underset{\sim}{\infty}$ & $\underset{\sigma}{\infty}$ & $\begin{array}{l}\sim \\
\forall \\
\forall\end{array}$ & $\begin{array}{l}\mathcal{D} \\
\tilde{m}\end{array}$ & $\begin{array}{l}\varrho \\
m \\
\mathfrak{m}\end{array}$ & 年 & $\stackrel{\infty}{\infty}$ & $\begin{array}{l}0 \\
0 \\
0\end{array}$ & $\begin{array}{l}+ \\
\sigma \\
a\end{array}$ & $\begin{array}{l}0 \\
0 \\
\infty\end{array}$ & $\underset{8}{q}$ & $\frac{\pi}{\sigma}$ & 응 & $\begin{array}{l}\overrightarrow{0} \\
a\end{array}$ & 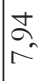 & $\begin{array}{l}\wp \\
\wp\end{array}$ \\
\hline
\end{tabular}

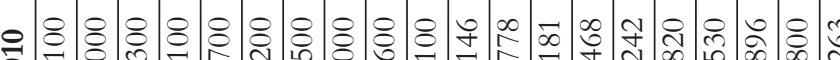

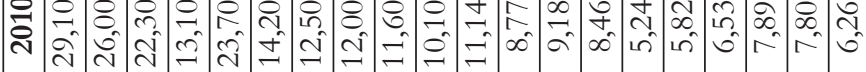

E

$\stackrel{20}{\circ}$

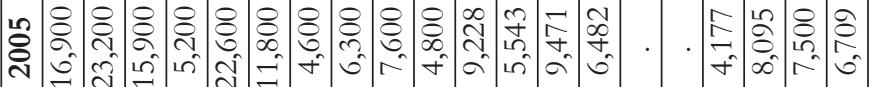

$\curvearrowright$

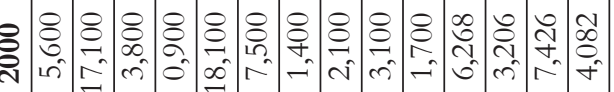

(-)

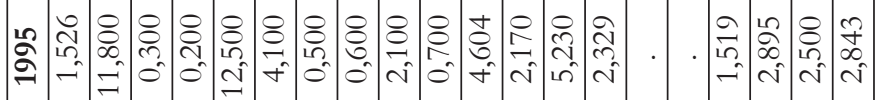

咅

\section{ஓ}

Љำ

$8 \underset{-\infty}{8}$

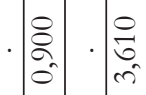

$\underset{\substack{a \\ \stackrel{n}{\sim}}}{n}$

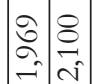

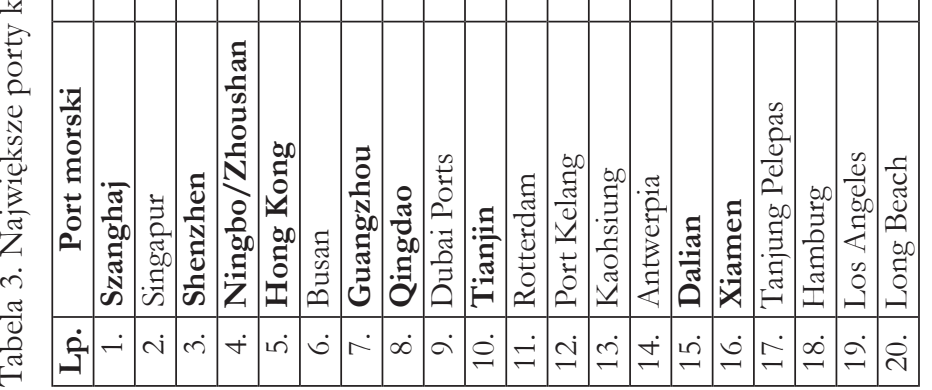

章

क.

ริ

$\underset{1}{2}$

悹

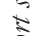

2

*ี

है

8

돈.

용

₹ै

है

व

¿.

है

운

इ.

है

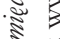

*

ज्ञे

8

ำ

ट्य

$\because \stackrel{0}{\circ}$

జ

a

है है

ह ज्ञ

츨 흔

₹

$=$

$\stackrel{\ddot{0}}{\overline{0}}$ 
Chińskie porty należą nie tylko do największych, uwzględniając ich potencjał przeładunkowy i wielkość przeładunków, ale także do najbardziej wydajnych ${ }^{32}$. Przykładowo, w portach Tianjin i Qingdao w 2014 r. średnia wydajność wyniosła $125 \mathrm{TEU} / \mathrm{h} /$ statek $^{33}$, w Nansha 119 TEU/h/statek, w Yantian 117 TEU/h/statek, w Ningbo 107 TEU/h/statek, zaś w Xiamen 90 TEU/h/statek ${ }^{34}$. Szybkość obsługi ładunków (szczególnie skonteneryzowanych) w portach jest obecnie jednym z głównych wyznaczników jakości usług przeładunkowych i czynników konkurencyjności portów morskich. Jest ona szczególnie istotna w sytuacji, gdy za jedna z głównych barier rozwoju handlu międzynarodowego, w opinii specjalistów, uważana jest kongestia portowa.

\section{Wyzwania stojące przed chińskimi portami morskimi}

Jak można zaobserwować z praktyki, w chińskim sektorze portowym w nadchodzących latach będą dominowały dwa wyraźne trendy: green port development, tj. zrównoważony rozwoju portów oraz smart ports. Dążenie do zrównoważonego rozwoju portów morskich, powszechne w krajach wysoko rozwiniętych, znajduje zrozumienie także w Chinach. Wiele jest przykładów zrównoważonych (eko) miast w całym kraju, między innymi Shenzen i Tianjin. W strategii ich rozwoju głównymi celami są: eliminacja wszystkich szkodliwych emisji związanych z wykorzystaniem węgla, wykorzystywanie na większą skalę odnawialnych źródeł energii, dbanie o przyjazne środowisku naturalnemu zagospodarowanie przestrzenne miast.

Te działania przenikają też do sektora portowego wraz z realizacją koncepcji eko-portów, służącej zrównoważonemu rozwojowi portów morskich. Chińskie Ministerstwo Transportu ogłosiło wdrożenie pilotażowego projektu polegającego na utworzeniu w przyszłości zielonego portu niskowęglowego w Qingdao. Lokalne władze sfinansują wiele związanych z tym projektem inwestycji, między innymi w zakresie infrastruktury, energooszczędnych i inteligentnych technologii, ochrony środowiska, zautomatyzowanych terminali. Podobne rozwiązanie przyjęto w delcie Rzeki Perłowej, gdzie Hongkong zamierza wdrożyć obowiązkową kontrolę emisji do atmosfery szkodliwych gazów związanych z eksploatacją obsługiwanych tam statków. Przede wszystkim chodzi o podniesienie czystości powietrza zanieczysz-

32 Wydajność obsługi przeładunkowej mierzy się liczbą TEU przeładowanych na statku w ciągu godziny. Jest ona uzależniona głównie od parametrów wykorzystywanych urządzeń przeładunkowych i sprzętu, wydajności pracy zatrudnionych.

33 W poszczególnych portach obsługą usługobiorców zajmują się operatorzy terminali. W porcie Tianjin do najbardziej wydajnych należą Tianjin Port Pacific International 144 TEU/h/statek (2. miejsce na świecie) oraz Tianjin Port Alliance Internatinal $132 \mathrm{TEU} / \mathrm{h} /$ statek (5. miejsce na świecie).

34 Review of Maritime Transport..., s. 70. 
czanego przez środki transportu drogowego i morskiego. Wprowadzenie tego typu pomiarów planują także władze Guangzhou. Będzie to pierwszy w Chinach projekt obszaru kontroli emisji (emission control area ECA) ${ }^{35}$.

W portach krajów wysoko rozwiniętych (również polskich) wdrażane są projekty typu smart port, oznaczające poszukiwanie i wprowadzanie innowacyjnych inteligentnych rozwiązań, poprawiających efektywność i ekologiczność funkcjonowania portów morskich. Są one związane z poszukiwaniem sposobów poprawy konkurencyjności portów. Rozwój globalnych logistycznych łańcuchów dostaw zmusił operatorów portowych na całym świecie do integracji poziomej i pionowej z wieloma innymi uczestnikami tych łańcuchów (przewoźnikami lądowymi i morskimi, operatorami logistycznymi, konkurencyjnymi operatorami portowymi, gestorami ładunków, dystrybutorami). Wiąże się to z koniecznością wdrażania nowoczesnych systemów technologicznych i informatycznych. Głównym celem tworzenia inteligentnych portów jest integracja tych różnych systemów, co umożliwi optymalizację przepływu ładunków w łańcuchach logistycznych (oczywiście przyspieszając ich obsługę i zwiększając bezpieczeństwo w portach). Władze chińskich portów, podążając drogą zagranicznych konkurentów, poszukują w tym zakresie własnych innowacyjnych rozwiązańn ${ }^{36}$.

Pomimo ogromnych sukcesów, jakie chińskie porty odniosły w ostatniej dekadzie na międzynarodowych rynkach usług portowych, borykają się stale z licznymi problemami. Poza zapewnieniem przepustowości terminali, odpowiadającej popytowi zgłaszanemu przez usługobiorców (co wiązało się z koniecznością podjęcia bardzo ambitnych programów inwestycyjnych w licznych portach), chiński sektor portowy ma problem z brakiem wysoko wykwalifikowanych pracowników (niezbędnych do obsługi nowoczesnego wyposażenia technicznego) oraz zbyt mała głębokością akwenów portowych (większość portów zapewnia głębokości do $10 \mathrm{~m}$, co dziś jest niewystarczające do obsługi największych kontenerowców o zanurzeniu ponad $15 \mathrm{~m}$ ), a szczególnie ważnym wyzwaniem na przyszłość pozostaje problem ochrony środowiska naturalnego.

Warto też wspomnieć o działaniach podejmowanych w kierunku optymalizacji przepustowości chińskich portów. Zrealizowane w ostatnich dekadach ambitne programy inwestycyjne, służące zaspokojeniu rosnącego popytu na usługi portowe, znacznie zwiększyły przepustowość terminali portowych. Wysokie tempo wzrostu obrotów portowych zostało zahamowane przez globalny kryzys końca pierwszej dekady XXI w. Wydaje się jednak, że chińskie porty nie ucierpiały znacząco z tego powodu i po 2010 r. popyt na ich usługi na ogół nadal wzrastał. W 2015 r. widoczne były spadki (choć niewielkie) przeładunków w niektórych portach. Jednak ich potencjał przeładunkowy znacznie przekracza obecne zapo-

35 China ports..., s. 21.

36 Ibidem, s. 23. 
trzebowanie na obsługę portowa. W przypadku terminali kontenerowych nadwyżka potencjału nad popytem wynosi około $50 \mathrm{mln} \mathrm{TEU}^{37}$ i do 2030 r. może się podwoićs ${ }^{38}$. Do najważniejszych przyczyn tego stanu można zaliczyć spadek obrotów chińskiego handlu zagranicznego, zaostrzającą się konkurencję na rynkach usług portowych, w tym pomiędzy portami Chin, a także wzrost kosztów pracy. Rząd chiński, w którego gestii pozostaje wyznaczanie najważniejszych kierunków rozwoju sieci krajowych portów morskich, wezwał rządy regionów i zarządy największych portów do podjęcia działań w kierunku optymalizacji procesów usługowych i zdolności przeładunkowych przez integrację portów. Proces integracji pięciu portów już się rozpoczął i objął: Ningbo, Zhoushan, Jiaxing, Taizhou i Wenzhou ${ }^{39}$. Powołano nowy podmiot do zarządzania nimi - Zhejiang Port Investment Operation Group (ZPIO). Port w Tianjin współpracuje z Hebei Port Group, która jest operatorem kilku portów, w tym: Tangshan, Huanghua i Qinhuangdao w prowincji Hebei w północnych Chinach. Obie grupy utworzyły joint venture Bohai Tianjin-Hebei Port Investment and Development Company, która formalnie ma zarządzać terminalami portowymi, ale także koordynować podejmowane w nich inwestycje. Obecnie najbardziej złożona i trudna, zdaniem specjalistów, wydaje się restrukturyzacja portów w północno-wschodnich Chinach. Chodzi o integracje portów: Dalian, Jinzhou i Yingkou i Qinhuangdao ${ }^{40}$. Proces ten będzie zapewne długotrwały.

Nie wiadomo, jak na funkcjonowanie i wolumen przeładunków chińskich portów w przyszłości wpłynie realizacja koncepcji Nowego Jedwabnego Szlaku, zaprezentowanej jesienia 2013 r. przez lidera Chińskiej Republiki Ludowej Xi Jinpinga. Jej nazwa odwołuje się do dawnego szlaku handlowego o długości około 12 tys. km, łączącego Chiny z Bliskim Wschodem i Europa, który był wykorzystywany przez kupców od III w. p.n.e. do XVII w. n.e., kiedy odkryto morską drogę do Chin. Transportowano nie tylko jedwab, ale także żelazo, złoto, papier oraz wyroby jubilerskie, a miasta leżące na tym szlaku bogaciły się na handlu.

Realizacja koncepcji lądowego i morskiego Nowego Jedwabnego Szlaku, czyli projektu „Jeden pas, jeden szlak" (one belt, one road), zakłada utworzenie sieci korytarzy transportowych, które będą łączyły Chiny z krajami Unii Europejskiej.

\footnotetext{
37 Chiny nadal tna zdolności przeładunkowe portów, www.logistykamorska.pl (dostęp: 26.08.2016).

38 Trzeba jednak zauważyć, że w działalności eksploatacyjnej portów morskich nadwyżka potencjału usługowego terminali nad aktualnym popytem na ich usługi jest zjawiskiem normalnym i pożądanym (na wypadek nagłego wzrostu popytu wywołanego zmianami na rynkach towarowych), jednakże problem może stanowić ustalenie jej optymalnej wielkości (gdyż jej występowanie wiąże się z koniecznością ponoszenia kosztów utrzymania niewykorzystywanego potencjału produkcyjnego). Zob. China brings major ports together, www.portstrategy.com (dostęp: 29.08.2016).

39 Port Ningbo w 2013 r. zajął pozycję lidera wśród największych portów morskich Chin, deklasując port w Szanghaju dzięki połączeniu jego potencjału z portem w Zhoushan.

40 Chiny nadal tnq...
} 
Oznacza to budowę bądź modernizację przede wszystkim kolejowych połączeń handlowych między Europą a Azją, dróg, portów (terminali) lądowych i morskich oraz lotnisk, a także tworzenie infrastruktury przesyłowej (ropociagów, gazociągów) i telekomunikacyjnej ${ }^{41}$.

Chiny promują intensywnie ideę Nowego Jedwabnego Szlaku, którego efekt finalny ma być widoczny w 2049 r., w setną rocznicę proklamowania Chińskiej Republiki Ludowej. Jest to zarazem nowa marka biznesowa, firmująca ideę integracji gospodarczej Azji z Europa, która może zmienić dotychczasowy geopolityczny porządek świata ${ }^{42}$. Połączenie Europy i Azji lądowymi szlakami handlowymi ma uniezależnić dziesiątki krajów od szlaków morskich. Korytarze transportowe mają biec wzdłuż całego azjatyckiego kontynentu, na lądzie - częściowo starym wielkim szlakiem, włączając do współpracy przy realizacji projektu azjatyckie republiki poradzieckie. Maja powstać także nowe szlaki, np. przez Indie, Iran, Rosję, Bałkany, kraje Unii Europejskiej, w tym Polskę (jako bramę, przez którą na rynki krajów Unii Europejskiej mają być przewożone chińskie towary ${ }^{43}$. Sceptycy wskazują jednak, że obecnie tylko 3,5\% chińskiego eksportu do Unii Europejskiej trafia drogą lądowa, głównie ze względu na ogromną dysproporcję między zdolnościami ładunkowymi statków i pociagów czy samochodów ${ }^{4}$. Wydaje się zatem, że rozwój połączeń lądowych w omawianych relacjach może raczej uzupełnić transportową obsługę ładunków handlu zagranicznego realizowaną dotychczas przez chińskie porty morskie i żeglugę morska, niż ją zastąpić.

\section{Podsumowanie}

Ze względu na cechy portów morskich jako ogniw lądowo-morskich łańcuchów transportowych, elementów systemu infrastruktury transportowej, obiektów, w których jest prowadzona różnorodna działalność gospodarcza oraz ze względu na ich relacje z bliższym i dalszym otoczeniem należy je postrzegać zarówno w kategoriach prawno-administracyjnych, przestrzennych, technicznych, jak i ekonomicznych oraz społecznych, doceniając realizowane przez nie funkcje gospodarcze. Działal-

\footnotetext{
${ }^{41}$ www.wiadomosci24.pl/artykul/kluczowy_hub_europy_w_polsce_chiny_chca_wlaczyc_jedwabny_szlak_349871.html (dostęp: 22.09.2016).

42 K. Majszyk, B. Niedziński, Nowy jedwabny szlak prazyniesie korayśsi. Nie tylko Chinom, www.biznes.gazetaprawna.pl (dostęp: 20.09.2016).

43 A. Koniecka, Wielkie projek.ty: nowy jedwabny šlak, www.biznesistyl.pl (dostęp: 22.09.2016).

44 Jeden pociag jadący z Chin do Europy zabiera na platformach kolejowych 41 kontenerów 40-stopowych. Dla porównania, wielkie statki kontenerowe moga zabrać na pokład 18-19 tys. TEU. Przewozy kolejowe są rozwiązaniem atrakcyjnym w przypadku pilnych dostaw, opóźnień w produkcji, braku miejsca na statkach, zwłaszcza dla załadowców, którzy nie chcą lub nie mogą korzystać z transportu lotniczego (około czterokrotnie droższego od kolejowego).
} 
ność usługowa portów, służąca tworzeniu wartości dodanej, związana z realizacją głównego zadania, czyli wszechstronną obsługą ładunków i środków transportu, jest nie do przecenienia zarówno dla najbliższego otoczenia i społeczności lokalnej, często dla gospodarki regionu i kraju, jak i - w przypadku największych portów świata, a do takich zaliczane są wielkie porty chińskie - dla handlu światowego, globalnych łańcuchów logistycznych i międzynarodowego systemu transportowego.

Należy podkreślić ogromną rolę, jaką obecnie chińskie porty morskie odgrywają w obsłudze ładunków międzynarodowego handlu morskiego, kształtowaniu kierunków przebiegu szlaków żeglugowych o znaczeniu światowym oraz funkcjonowaniu globalnych logistycznych łańcuchów dostaw. Wolumen przeładowywanych w nich różnorodnych ładunków, który jest efektem otwarcia chińskiej gospodarki na kontakty z zagranica, wyjątkowo szybkiego tempa jej rozwoju, rozwoju handlu międzynarodowego, popularnego w ostatnich dekadach zjawiska offshoringu, a także ewolucji systemu zarządzania chińskimi portami i realizacji ogromnych portowych projektów inwestycyjnych, służących dostosowaniu potencjału usługowego do popytu zgłaszanego na rynkach usług portowych, powoduje, że w rankingu największych portów morskich świata zajmują one czołowe pozycje ${ }^{45}$. Sytuacja na rynkach usług portowych zmienia się bardzo dynamicznie, co wymaga od zarzadów portów oraz operatorów terminali szybkiej reakcji w celu dostosowania się do niej. Chińskie porty, podobnie jak porty w krajach wysoko rozwiniętych, zmagaja się z problemami ochrony środowiska naturalnego, koniecznością wdrażania inteligentnych rozwiazań poprawiających efektywność i ekologiczność ich funkcjonowania, zapewnienia odpowiednich głębokości basenów portowych i wieloma innymi. Wszystkie te problemy muszą zostać rozwiązane w celu utrzymania i podniesienia konkurencyjności portów, zwłaszcza wobec wewnątrzkrajowej i międzynarodowej konkurencji portowej (w szczególności ze strony Singapuru, portów Tajwanu i Korei Południowej), a także konkurencji (w relacjach z Bliskim Wschodem i Europa) transportu lądowego (w postaci Nowego Jedwabnego Szlaku).

45 Niekiedy występują problemy z ustaleniem miejsca danego portu w portowych rankingach (międzynarodowym lub krajowym) z powodu braku możliwości uzyskania danych statystycznych. Jeszcze w latach $80 . \mathrm{XX}$ w. wielkość przeładunków w chińskich portach podawano łącznie, wyróżniając jedynie (z oczywistych powodów) Hongkong oraz Szanghaj. 


\section{SUMMARY}

\section{OPERATION AND DEVELOPMENT OF SEA PORTS IN PEOPLE'S REPUBLIC OF CHINA}

Seaports, being elements of national and international transport systems, are areas for carrying out various economic activities, mainly handling cargo and passengers (in the process of transport) and the means of transport. A special role in today's markets of port services, play Chinese seaports, in the last decades going through the evolution that brought them to the tops of seaports world rankings. The article presents the position of ports in the landsea transport chains and their economic functions, with the help of which the importance of these objects for the economies of cities, regions and countries is determined. Particular attention was paid to Chinese ports, which role in global maritime transport is not to be underestimated. 